\title{
Seasonal Variability of Wind Stress Curl and Vorticity of Surface Currents in the North Atlantic
}

\author{
A.B. Polonskii, I.G. Shokurova, P.A. Sukhonos \\ Marine Hydrophysical Institute, Russian Academy of Sciences, Sevastopol, \\ Russian Federation \\ e-mail: apolonsky5@mail.ru,igshokurova@mail.ru,pasukhonis@mail.ru
}

\begin{abstract}
Seasonal variability of spatial distribution and values of the wind stress curl and vorticity of the surface currents in the North Atlantic are analyzed based on the ORA-S3 reanalysis data for 19592011. It is revealed that placement of two constant cyclonic and anticyclonic spacious areas in the surface currents' vorticity distribution corresponds, in general, to the positions of the main oceanic gyres - the North Atlantic Sub-polar cyclonic and Subtropical anticyclonic gyres. As for distribution of the wind stress curl, the areas with cyclonic and anticyclonic surface currents' vorticity are of more complex heterogeneous structure as compared to the similar ones. Strengthening of the cyclonic wind stress curl and vorticity of the surface currents in the sub-polar zone takes place in January, weakening - in July. Strengthening of the anticyclonic wind stress curl and vorticity of the surface currents in the subtropical zone is observed in January and June-July and weakening in May and September-October. Correlation between the intra-annual changes of the wind stress curl and the surface currents' vorticity values averaged over the area of the North Atlantic Subtropical Gyre is 0.86, whereas the same value resulted from averaging over the area of the North Atlantic Sub-polar Gyre -0.98 . The values of the wind stress and its curl obtained by S. Hellerman and M. Rosenstein in 1983 are confirmed (though in some later papers they were characterized as overestimated).
\end{abstract}

Keywords: wind stress curl, vorticity of surface currents, seasonal variability, the North Atlantic.

DOI: 10.22449/1573-160X-2015-2-39-50

(C) 2015, A.B. Polonskii, I.G. Shokurova, P.A. Sukhonos

(C) 2015, Physical Oceanography

\section{Introduction}

The Atlantic Ocean plays an important role in climatic changes in the AtlanticEuropean region. The heat transport by the Gulf Stream and the North Atlantic Current to high latitudes has a significant impact on the climate in Europe. This leads to the importance of studying the spatio-temporal variability of the current field and also wind field, which forms upper ocean circulation. Key parts of the large-scale circulation in the North Atlantic, allocated according to the average long-term observations, are the Subtropical Gyre (STG) and the Subpolar Gyre (SPG). The STG is the system of currents formed by the Gulf Stream from the west, by its prolongation - the North Atlantic Current from the north, by the Canary Current from the east and by the North Equatorial Current from the south. The SPG includes the Labrador, the North Atlantic, Irminger and Greenland Current [1].

It is well known that the location of oceanic gyres is determined by spatial structure of the large-scale atmospheric circulation. The STG is situated in the area of anticyclonic wind stress curl and the SPG - in the area of cyclonic one. In its turn the distribution of wind stress curl is determined by the position of permanent winds - the trade winds in the tropics and western winds in the middle latitudes [2].

Spatial distribution of wind stress curl and its seasonal variability for the World Ocean [3 -6] and its separate regions, including the North Atlantic [7 - 10] are well-studied nowadays. Calculation and analysis of season average wind stress PHYSICAL OCEANOGRAPHY NO. 2 (2015) 
curl for the whole World Ocean were carried out in [3] according to the wind expeditionary data with $2 \times 2^{\circ}$ spatial resolution within $1870-1976$ period, in [4] data with $1 \times 1^{\circ}$ spatial resolution within 1850 - 1979 period and in $[5,6]$ - the ECMWF (European Centre for Medium-Range Weather Forecasts) data with $2.5 \times 2.5^{\circ}$ spatial resolution within $1980-1986$ period. Spatial distributions of wind stress curl, obtained in the aforementioned articles, don't differ from each other significantly.

Fields of wind stress curl in the North Atlantic for January and July are calculated on the two-degreed grid according COADS monthly data set for the 1947 - 1988 in work [7]. It is shown that the cyclonic wind stress curl in the middle latitudes and subpolar zone intensifies in the winter season and in the Intertropical Convergence Zone (ITCZ) experiences meridional shifts and intensifies during the summer season. Annual cycle of wind stress curl was studied for the area of the Norway and Greenland Seas according to the 1955 - 1987 data in [8]. Wind circulation in these areas is having a cyclonic character during the whole year. The value of wind stress curl increases in winter and decreases in summer. The seasonal cycle of wind stress curl over the eastern STG boundary was analyzed by using of the wind expeditionary data in [9]. There are observed cyclonic vorticity of the wind near the continental boundaries and anticyclonic one in the open sea. In summer, there is intensification of cyclonic vorticity and stretching of cyclonic area in the meridional direction to the pole. The seasonal cycle of wind stress curl for the Tropical Atlantic is researched in [10] under the data with $1,875 \times 1,875^{\circ}$ spatial resolution for April 1982 - September 1984 period. It is shown that the maximum meridional gradient of wind stress curl in the ITCZ is observed from July to September. Thus, the spatio-temporal structure of the wind stress curl field is well studied. However, the value of the wind stress and its curl vary considerably in different studies. This is due to the use of different data types, their different spatio-temporal averaging and methodological differences in the determination of the drag coefficient.

From the classical theory it is known that the wind spatial heterogeneity is one of the main sources of vorticity of surface current in the ocean [11]. The modern re-analysis data of the current velocities allows performing calculations of vorticity of currents on a regular grid over a long period of time. Information about vorticity of surface currents allows us to study the spatio-temporal variability of the structure of large oceanic gyres, as well as to carry out a joint analysis of the spatio-temporal variability of vorticity of surface currents and wind stress curl, which is the main objective of the present work.

\section{Data and methods}

To achieve the objective set we applied the data on the wind stress and current fields from the ORA-S3 ocean re-analysis [12] for the period from January 1959 to December 2011. The data spatial resolution is $1 \times 1^{\circ}$, and in the equatorial zone ( $\pm 10^{\circ}$ of the latitude) $-0.3^{\circ}$ in the meridional direction and $1^{\circ}$ in the zonal one. Wind stress data in ORA-S3 re-analysis is used from the ERA-40 atmosphere reanalysis [13] for the period from January 1959 to June 2002 and NWP operational analysis for the period from July 2002 to December 2011.

Wind stress curl for each month was calculated under the following formula

$$
\operatorname{rot}_{z} \vec{\tau}=\frac{\partial \tau_{y}}{\partial x}-\frac{\partial \tau_{x}}{\partial y}\left(\mathrm{~N} / \mathrm{m}^{3}\right),
$$

where $\tau_{x}, \tau_{y}$ are zonal and meridional components of the wind stress vector. 
Vorticity of surface currents for each month was calculated under the following formula:

$$
\operatorname{rot}_{z} \vec{V}=\frac{\partial V_{y}}{\partial x}-\frac{\partial V_{x}}{\partial y}\left(\mathrm{~s}^{-1}\right),
$$

where $V_{x}, V_{y}$ are zonal and meridional components of the velocity vector on $15 \mathrm{~m}$ horizon.

It should be noted that the vertical axe $z$ is up-directed, i.e. during the analysis of the spatial distribution of the average vorticity values under anticyclonic (cyclonic) vorticity the negative (positive) values are considered.

Calculations were carried out for each month in the each node of the grid. As a result, for each calculation point we were obtained monthly time series of wind stress curl and vorticity of surface currents in the North Atlantic for the 53-year period. Annual vorticity cycle for individual areas is computed from monthly values averaged within area. The analysis of seasonal variability of the spatial distribution of the wind stress curl and vorticity of the surface current focuses on the middle month of every season - January, April, July and October.

\section{Analysis of the results}

Seasonal variability of the spatial structure of the wind stress field and its curl. Fields of wind stress and its curl for January, April, July and October averaged over the studied period are shown on Fig. 1. Spatial variability of the absolute wind stress value in the North Atlantic has the characteristic latitude features for all seasons, which are associated with the large-scale structure of the winds in the Northern hemisphere. Increase of the wind stress module value is observed in the area of the north-eastern trade wind (between 10 and $20{ }^{\circ} \mathrm{N}$ ), then its decrease (up to zero around $30^{\circ} \mathrm{N}$ ) and gradual increase northward with the western wind maximum values is marked.

In winter the wind stress module increases both in the area of the trade winds and the one of the western winds (Fig. 1,a). Its maximum values are observed in the area of the western winds. At this time the meridional component of the wind stress vector is substantial. In summer wind stress in the area of the western winds weakens and becomes lower (under the module) than wind stress in the area of the trade winds (Fig. 1, c). In autumn the trade winds weaken and the wind stress in the area of the western winds increases (Fig. 1,d). At that time the meridional component of wind stress is minimal - the trade winds and the western winds has mainly the zonal direction. The obtained seasonal variability of the spatial structure of the wind stress was noted before in $[5,6]$.

Spatial structure of wind stress curl is quasizonal on the whole for all seasons. There is the narrow cyclonic curl band (ITCZ) in the southern part of tropics, the anticyclonic curl area - in the northern part of tropics and in subtropical zone, the cyclonic curl one - in temperate latitudes and subpolar zone (Fig. $1, e-h$ ). There are two centers with the highest values of wind stress curl in the anticyclonic area Azores and Bermuda atmospheric pressure maxima. These two maxima intensify in winter and weaken in summer months. It should be emphasized that the wind stress curl maximum in the area of the Azores has constant character and is marked in all months of the year. The extreme value of wind stress in the northern cyclonic area curl corresponds to the Icelandic Low. 

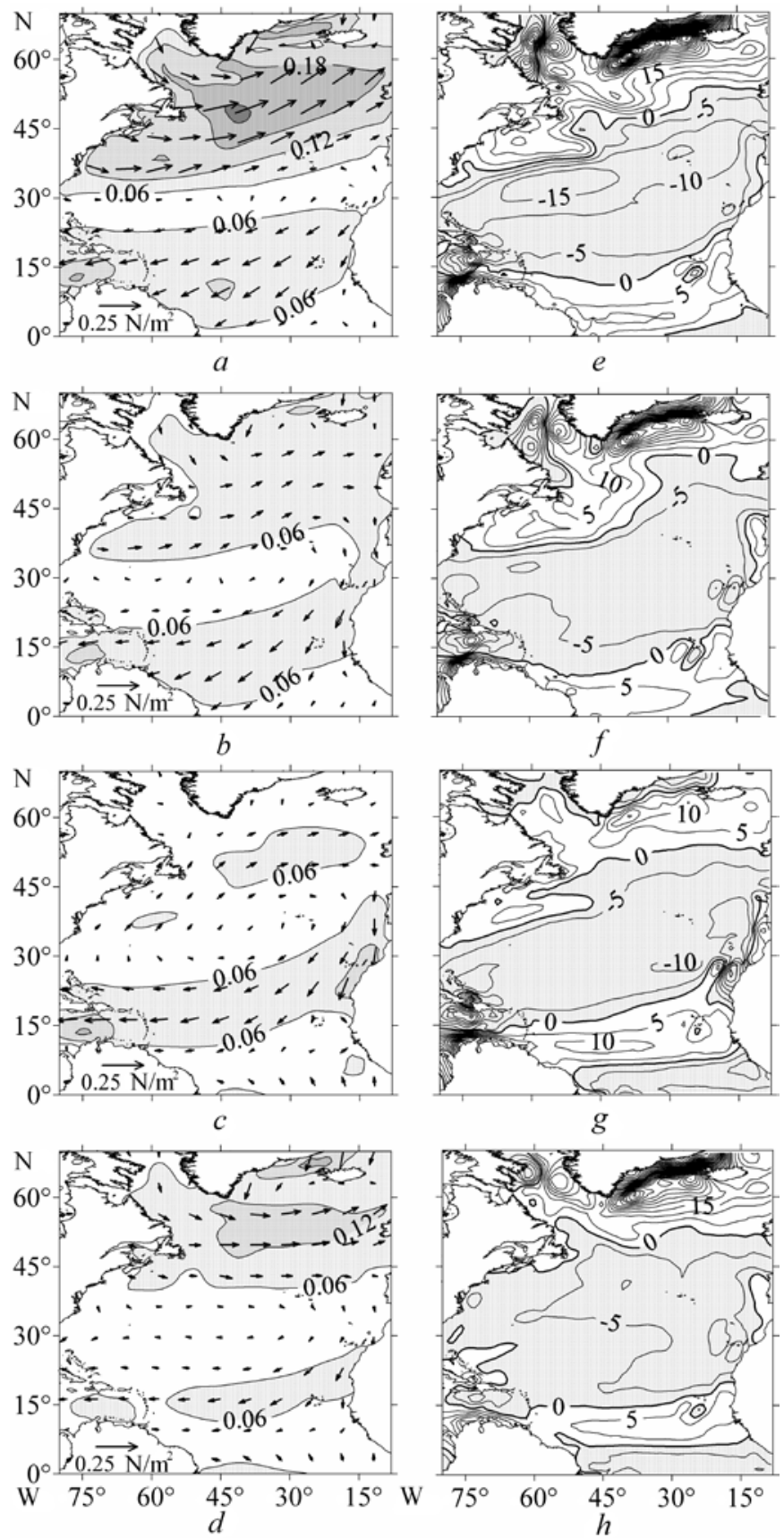

Fig. 1. Fields of wind stress, $\mathrm{N} / \mathrm{m}^{2}$ ( $a, b, c, d$; the intensity of the darkening of the hatch characterizes the increase of wind stress curl module) and wind stress curl $\times 10^{-8} \mathrm{~N} / \mathrm{m}^{3}(e, f, g, h$; anticyclonic wind stress curl areas are hatched) in the North Atlantic, averaged for 1959 - 2011 period for January ( $a$, $e)$, April $(b, f)$, July $(c, g)$ and October $(d, h)$

Position and dimensions of anticyclonic and cyclonic wind stress curl areas change every season. In all seasons, except the autumn, anticyclonic wind stress 
curl field axis is tilted in a southwesterly direction. In the winter cyclonic wind stress curl area in the northern part of the North Atlantic increases along with the strengthening of the western winds (Fig. 1,e). In the summer the southern and northern boundaries of anticyclonic area shift northward (Fig. 1, g). In autumn these boundaries are situated zonally (Fig. $1, h$ ). Anticyclonic area size grows in the winter months and becomes smaller by the end of summer - the beginning of autumn, as it has already been noted in [14].

Near the coasts of Africa in summer and spring the increase of cyclonic wind vorticity areas is observed; it leads to the upwelling zones growth that was shown in [9] on the basis of wind expeditionary measuring data. In the western ITCZ area maximum seasonal variations of the wind stress curl field are marked, that affect seasonal variability of the hydrophysical characteristics in the area of the Equatorial Counter Current, as has noted in $[15,16]$.

Spatial distribution of wind stress curl over the North Atlantic calculated in our paper agrees qualitatively with the results of the works [3 - 7], which analyzed data from another time period. The obtained values of the wind stress curl are consistent with the data [3]. However, according to our calculations and the results of [3], these values are about $20-30 \%$ more than in [4]. It is probably related to the greater data smoothing, carried out in [4]. Difference of our results from the ones published in [5 - 7] is in the spatial mismatch of individual isolines in anticyclonic area. This is due to the fact that in $[5,6]$ the averaging has been performed under a significantly short time period (7 years), while in our article the 53-year time interval has been considered, and, as is known, there is a significant inter-annual variability in the wind field. It also relates to the comparison with results of the article [7], where averaging has been made under time-shifted and shorter data series.

Seasonal variability of the spatial structure of surface current field and its vorticity. In all seasons there are the Gulf Stream, the North Equatorial and Caribbean Currents well-marked in the surface current field. Maximum velocities are monitored in the Caribbean Current (Fig. 2). Also the intense seasonal variability is found in the field of currents. In October and January the East Greenland Current strengthens. In January the Labrador, North-Atlantic and North Equatorial Currents also become more intense. In July the North Equatorial Current, especially its eastern part, weakens. At the same time strengthening of the Canary Current is quite seen and it is consistent with the results obtained according to the expeditionary data in [17]. In July and October the Equatorial Counter Current and South Equatorial Current significantly strengthen as was noted in [18] under vessel drift data and in the other works.

Spatial distribution of vorticity of surface currents has a considerably complex structure as compared with wind stress curl, although while the presence of two large gyres (the STG and SPG) in the North Atlantic is generally confirmed (Fig. 2). If null vorticity isolines are considered as the boundaries between the gyres, you can see that a vast area of anticyclonic vorticity between $15-42^{\circ} \mathrm{N}$, corresponding to the STG, has a clear southern boundary.

However, the northern boundary has more complex structure. In addition, in the STG area there are fields with cyclonic vorticity characterized by small values 
of the opposite sign. This spatial distribution of the vorticity of surface current is a consequence of the fact that the source of currents vorticity in the ocean due to the spatial inhomogeneity of the wind is not the only one [19].
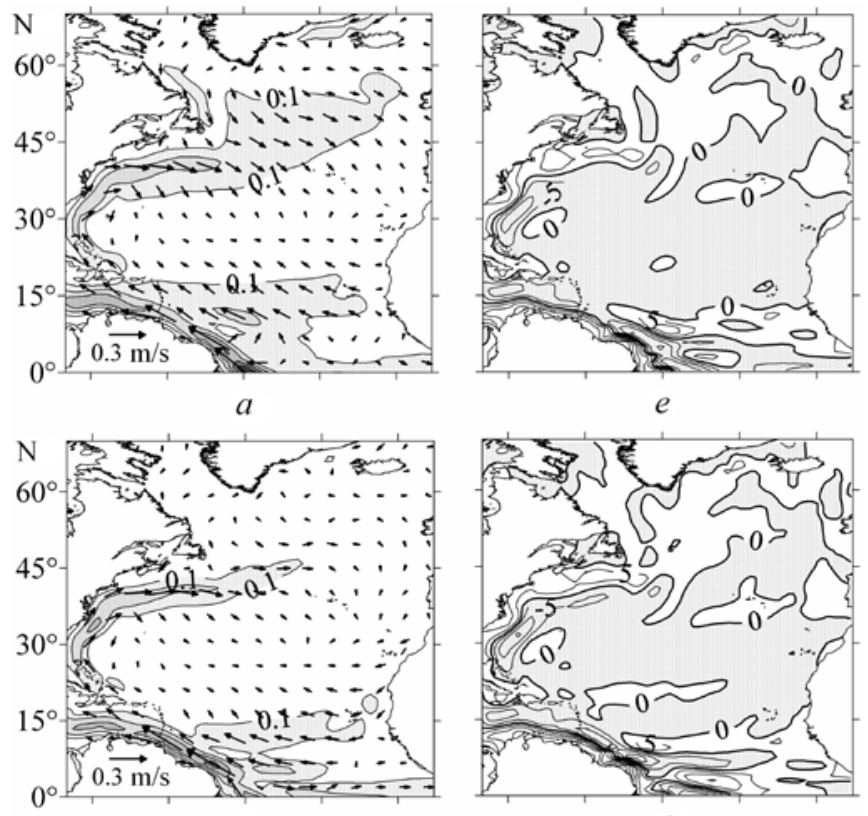

$b$
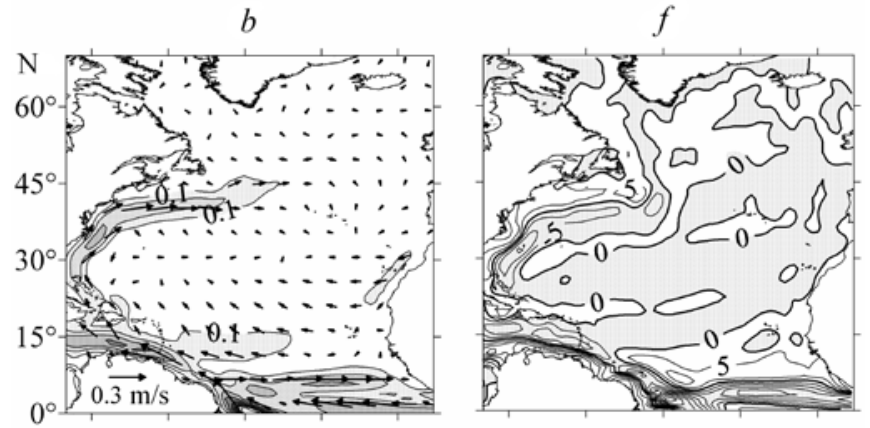

$c$
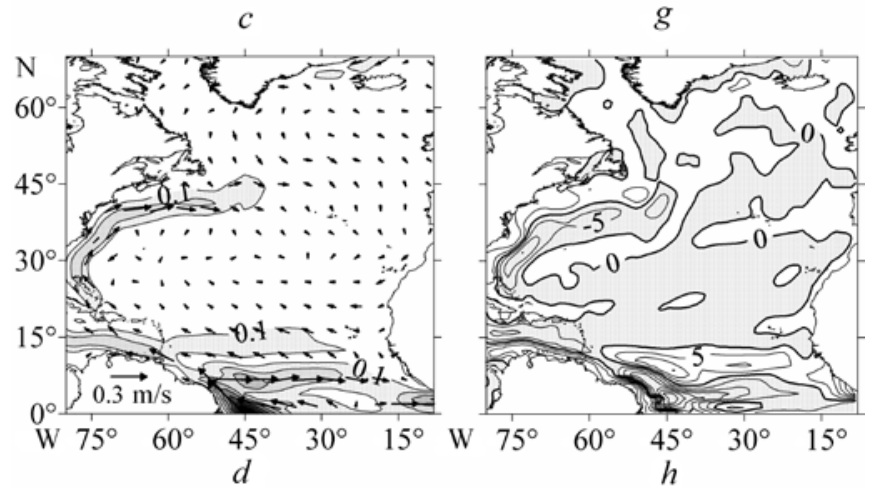

Fig. 2. Current velocity fields $(\mathrm{m} / \mathrm{s})$ on $15 \mathrm{~m}$ horizon $(a, b, c, d$; the intensity of the darkening of the hatch characterizes the increase of current velocity module contour interval $0.1 \mathrm{~m} / \mathrm{s}$ ) and vorticity of surface currents, $\times 10^{-7} \mathrm{~s}^{-1}(e, f, g, h$; anticyclonic vorticity areas are hatched) in the North Atlantic, averaged for 1959 - 2011 period for January $(a, e)$, April $(b, f)$, July $(c, g)$ and October $(d, h)$ 
Area with cyclonic vorticity of the surface current corresponding to the SPG is found in all seasons in $45-60^{\circ} \mathrm{N}$ latitudinal band. However it is more pronounced in the winter time. Southward of the STG between the North and South Equatorial Currents there is a band with cyclonic vorticity in the surface current field. Cyclonic vorticity strengthening occurs here in autumn along with the simultaneous intensification of the North Equatorial Current and Equatorial Counter Current.

The highest values of anticyclonic vorticity of the surface current are observed in all seasons in the area of the Gulf Stream and Caribbean Current that is related to the high velocity shift values in these jet flows, and also in the area of the South Equatorial Current. High values of cyclonic vorticity are marked in the tropics and coastal region between the Gulf Stream and North America.

In general spatial structure of current vorticity field remains in all seasons. Seasonal changes manifest in the shift of south boundary of the anticyclonic vorticity area relating to STG and in size change of the areas with cyclonic vorticity within this region. Similar to the wind stress curl, the south boundary of large-scale anticyclonic gyre is shifted northward in summer months. Such shift and increase of the zonal elongated area with cyclonic vorticity near the Azores Islands in summer and autumn can be interpreted as a reduction in the meridional size of the STG. In [20] it was referred to the meridional gyre size reduction on the results of archive hydrographic data processing. Shift of the north boundary of anticyclonic vorticity area of surface current in its north-western part is constrained by the mainland coastline influence [21].

In winter areas with cyclonic vorticity of surface current within the STG have minimum sizes, but in the summer and autumn months they increase due to seasonal variability of current strength. Thus, an increase in the autumn season of zonally elongated area of cyclonic vorticity in the eastern part of the ocean in the vicinity of $35{ }^{\circ} \mathrm{N}$ occurs simultaneously with the strengthening of the Azores Current, the position of which corresponds to the southern border of this area.

Model [22, 23] and theoretical [24] research shows that the area of cyclonic current vorticity situated in the vicinity of Gibraltar is a result of salt water runoff from the Mediterranean.

In all seasons we can observe the area with cyclonic vorticity of surface current in $30-35^{\circ} \mathrm{N} 40-50^{\circ} \mathrm{W}$ that can be caused by Gulf Stream branching into two streams - the North Atlantic and the Azores Current. The presence in the area of cyclonic loop by branching of the streams is noted in [25]. The other area with cyclonic vorticity near $30{ }^{\circ} \mathrm{N} 68{ }^{\circ} \mathrm{W}$ located in the region of the Gulf Stream recirculation is observed in all months of the study period.

We are to emphasize that the whole structure of the field of the vorticity of surface current is qualitatively consistent with the spatial distribution of currents, calculated on drifter data for the period from October 1992 to October 2002 [26].

Intra-annual variability of the zonal averaged wind stress curl and vorticity of surface currents. Taking into account the predominantly zonal character of spatial structure of wind stress curl and vorticity of surface currents the intraannual cycle of their zonal averaged values was calculated. Fig. 3 clearly demonstrates zonal regions with alternating cyclonic and anticyclonic wind stress 
curl (Fig. 3, a) and vorticity of surface currents (Fig. 3, b), remaining the same throughout the year.

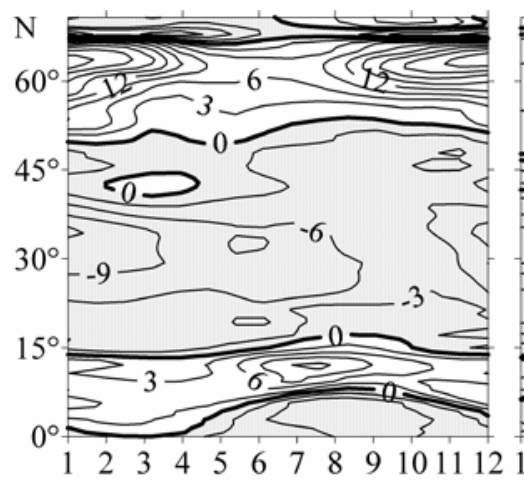

$a$

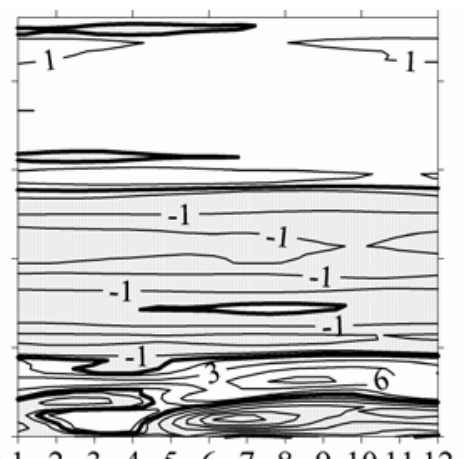

$b$

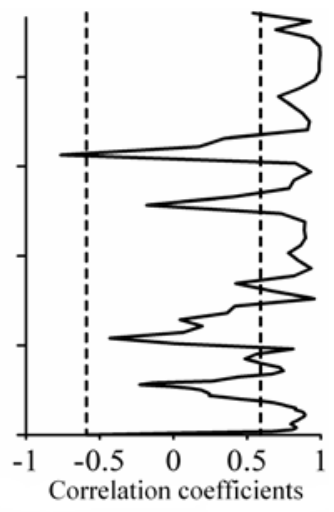

$c$

Fig. 3. Intra-annual variability of the zonal averaged wind stress curl $(a)$ and vorticity of surface currents $(b)$ in the North Atlantic (anticyclonic vorticity areas are hatched) and also the correlation coefficients among them ( $c$; dashed lines indicate $95 \%$ confidence intervals)

In the ITCZ the maximum value of cyclonic wind stress curl is marked in July - August (Fig. 3, a), which is consistent with the data of [7]. In the area of anticyclonic wind stress curl, located in on average per year within $15-50{ }^{\circ} \mathrm{N}$, strengthening of the wind stress curl is monitored in December - January. In the $50-70{ }^{\circ} \mathrm{N}$ zone maximum values of cyclonic wind stress curl are marked in November - January that is consistent to the strengthening of cyclonic vorticity in the Icelandic Low. In August - September it is clearly seen the seasonal shift of anticyclonic vorticity field and the ITCZ northward (Fig. 1, 3).

Zonal averaged vorticity of surface currents has the following intra-annual variability. In tropics the maximum values of cyclonic vorticity are marked in August - September, and the minimum ones - in January (Fig. 3, $b$ ). In the STG anticyclonic vorticity increases in absolute value in winter and summer. The increase of cyclonic vorticity in the SPG located northward of $42^{\circ} \mathrm{N}$ takes place in December - January.

Thus, the intra-annual changes in the zonal averaged values of wind stress curl and vorticity of surface currents in the North Atlantic qualitatively agree in latitudinal zones. But the zonally averaged STG north boundary is situated southward to the corresponding boundary of anticyclonic wind stress curl area. As mentioned above, this is due to the presence of the coastline in the north-western part of the water area, limiting the penetration of the subtropical gyre in the northern direction.

Meridional distribution of the value of correlation coefficients between the intra-annual cycle ranges of zonal averaged wind stress curl and vorticity of surface current is shown in Fig. 3, c. High positive values $(>0,8)$ are marked in middle latitudes $\left(50-68{ }^{\circ} \mathrm{N}\right)$, in subtropical zone - in the vicinity of the Azores high $(27-$ $36^{\circ} \mathrm{N}$ ) and in tropical zone. Negative correlation coefficient values correspond to the position of the boundaries with the different sign of the vorticity. 
Intra-annual variability of wind stress curl and vorticity of surface currents averaged over the STG and SPG areas. To analyze temporal variability of wind stress curl and vorticity of surface currents for the STG and SPG areas, gyre zone averaged vorticity values per each month were calculated. The area related to the STG was limited by $15^{\circ} \mathrm{N}$ from the south and by $40{ }^{\circ} \mathrm{N}$ from the north, and the area related to the SPG - by 50 and $65^{\circ} \mathrm{N}$ correspondingly. These areas were limited by the coasts longitudinally.

Graphs of the intra-annual cycle of vorticity, averaged under the mentioned areas throughout the whole studied period, are shown on Fig. 4. Intra-annual cycle of wind stress curl and vorticity of surface currents for the STG is featured by two minimums and two maximums. Weakening of wind stress curl (taking into the account the vorticity sign) occurs in May $\left(-4.84 \times 10^{-8} \mathrm{~N} / \mathrm{m}^{3}\right)$ and September $\left(-2.51 \times 10^{-8} \mathrm{~N} / \mathrm{m}^{3}\right)$ (Fig. 4, $a$ ), and weakening of vorticity of surface currents - in May $\left(-10.1 \times 10^{-8} \mathrm{~s}^{-1}\right)$ and October $\left(-9.52 \times 10^{-8} \mathrm{~s}^{-1}\right)$ (Fig. 4, b). Strengthening of wind stress curl and vorticity of surface currents occurs in winter and summer. The largest absolute magnitude values of wind stress curl $\left(-6.29 \times 10^{-8} \mathrm{~N} / \mathrm{m}^{3}\right)$ and vorticity of surface currents $\left(-11.0 \times 10^{-8} \mathrm{~s}^{-1}\right)$ are marked in January. The second maximum of the wind stress curl is observed in June $\left(-5.38 \times 10^{-8} \mathrm{~N} / \mathrm{m}^{3}\right)$ and vorticity of surface currents in July $\left(-10.9 \times 10^{-8} \mathrm{~s}^{-1}\right)$.
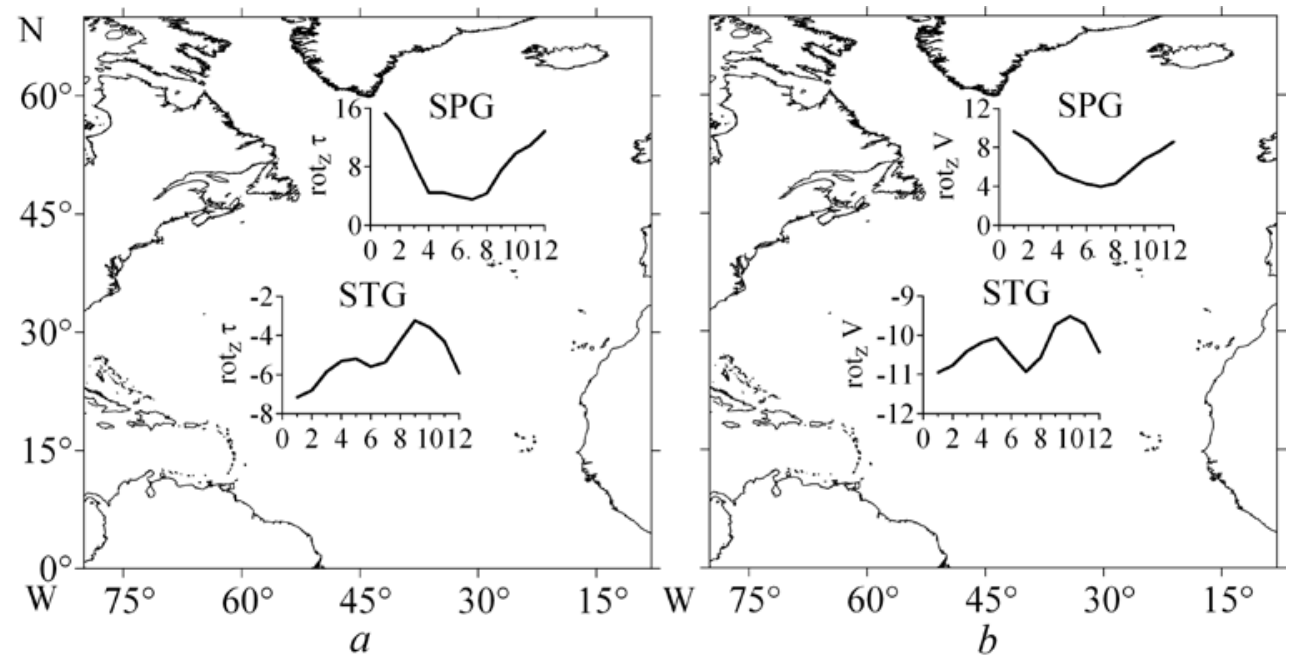

Fig. 4. Intra-annual variability of the wind stress curl $\times 10^{-8} \mathrm{~N} / \mathrm{m}^{3}(a)$ and vorticity of surface currents $\times 10^{-8} \mathrm{~s}^{-1}(b)$ averaged over the STG and SPG areas

In tropical and subtropical areas semi-annual component of the seasonal variability is observed both in the atmosphere and the ocean that is shown in many studies. The variability featured by two maxima (in summer and winter) and two minima (in autumn and spring) manifests not only in seasonal fluctuations of wind stress curl and vorticity of surface currents, but also in seasonal fluctuations of wind stress and wind velocity, sea-level pressure [6, 27], intensity of currents [28, 29], value of meridional transports [7, 30]. 
High values of cyclonic wind stress curl in the SPG are marked from September to March with their maximum in January, the low ones - from April to August with their minimum in July, as corresponds to the results of [8]. Maximum values of cyclonic wind stress curl are $15.3 \times 10^{-8} \mathrm{~N} / \mathrm{m}^{3}$, the vorticity of surface currents are $9.64 \times 10^{-8} \mathrm{~s}^{-1}$, minimum values are $3.53 \times 10^{-8} \mathrm{~N} / \mathrm{m}^{3}$ and $3.98 \times 10^{-8} \mathrm{~s}^{-1}$ accordingly.

Correlation between intra-annual values changes of wind stress curl and vorticity of surface currents, averaged over the STG area, is 0.86, over the SPG one -0.98 .

Strengthening of cyclonic wind stress curl and vorticity of surface currents in subpolar zone and anticyclonic vorticity in subtropical zone in January occurs synchronically due to the intensification of atmosphere zonal circulation (western and trade winds) in winter period. The second intensification of anticyclonic wind stress curl and vorticity of surface currents is observed only in subtropical zone in summer.

Thus, despite the complex structure of spatial distribution of vorticity of surface currents, there is a good agreement between intra-annual changes of the wind stress curl and the vorticity of surface currents averaged over the areas of large-scale gyres.

\section{Conclusion}

Research of the spatio-temporal variability of wind stress curl and vorticity of surface currents in the North Atlantic showed the following results.

The spatial distribution of wind stress curl calculated in the present work within 1959 - 2011 data well match the results of other studies, obtained under the different time periods. All in all our data confirm the evaluations of the values of wind stress and its curl, carried out by the authors of the article [3], being feature in some later works as the increased ones.

In the spatial structure of vorticity of surface currents the following areas are singled out: cyclonic vorticity area between North Equatorial and South Equatorial Currents, large-scale anticyclonic vorticity area representing to the STG, and cyclonic vorticity area representing the SPG. Spatial distribution of vorticity of surface currents has more complex structure than vorticity in the wind field. Anticyclonic vorticity area related to the STG includes sections with cyclonic vorticity, the dimensions of which vary depending on the season. It shows the important role of the other factors (in addition to wind stress curl) in the formation of the large-scale circulation structure of the World ocean upper layer.

On the whole spatial structure of wind stress curl and vorticity of surface currents maintains throughout the year. Seasonal variability of their spatial distribution manifests mainly in the shift of the boundaries of large-scale anticyclonic area in the north-eastern direction in summer season.

Nature of the intra-annual variability of wind stress curl and vorticity of surface currents, averaged over subtropical and subpolar zones, is different. In winter increase of the anticyclonic wind stress curl and vorticity of surface currents in subtropical zone is synchronic with the cyclonic vorticity intensification in subpolar zone. In summer there's the second maximum of anticyclonic wind stress 
curl and vorticity of surface currents (under the absolute value) in subtropical zone. Correlation between intra-annual changes of wind stress curl and vorticity of surface currents in the areas of large-scale gyres is 0.86 for the STG and 0.98 for the SPG that confirms the dominant role of the horizontal-inhomogeneous wind in the formation of the ocean upper layer circulation.

\section{REFERENCES}

1. Tomczak, M., Godfrey, J.S., 2003, “Regional oceanography: an introduction”, Delhi, Daya Books, 390 p.

2. Stommel, H.M., 1958, “The Gulf Stream: a physical and dynamical description”, Berkeley and Los Angeles, California, Univ. California Press, 230 p.

3. Hellerman, S., Rosenstein, M., 1983, "Normal monthly wind stress over the World ocean with error estimates”, J. Phys. Oceanogr., vol. 13, no. 7, pp. 1093-1104.

4. Harrison, D.E., 1989, "On climatological monthly mean wind stress and wind stress curl fields over the World ocean”, J. Clim., vol. 2, no. 1, pp. 57-70.

5. Trenberth, K.E., Olson, J.G. \& Large, W.G., 1989, “A global ocean wind stress climatology based on ECMWF analyses”, Climate and Global Dynamics Division, National Center for Atmospheric Research, 93 p, doi: 10.5065/D6ST7MR9.

6. Trenberth, K.E., Large, W.G. \& Olson, J.G., 1990, "The mean annual cycle in global ocean wind stress”, J. Phys. Oceanogr., vol. 20, no. 11, pp. 1742-1760.

7. Mayer, D.A., Weisberg, R.H., 1993, “A description of COADS surface meteorological fields and the implied Sverdrup transports for the Atlantic Ocean from 30-degrees-S to 60-degreesN”, J. Phys. Oceanogr., vol. 23, no. 10, pp. 2201-2221.

8. Jonsson, S., 1991, "Seasonal and interannual variability of wind stress curl over the Nordic Seas”, J. Geophys. Res., vol. 96, no. C2, pp. 2649-2659.

9. Bakun, A., Nelson, C.S., 1991, "The seasonal cycle of wind-stress curl in subtropical eastern boundary current regions”, J. Phys. Oceanogr., vol. 21, no. 12, pp. 1815-1834.

10. Henin, C., Hisard, P., 1987, "The North Equatorial Countercurrent observed during the Programme Francais Ocean Climat dans l'Atlantique Equatorial Experiment in the Atlantic Ocean, July 1982 to August 1984”, J. Geophys. Res.: Oceans (1978 - 2012), vol. 92, no. C4, pp. 3751-3758.

11. Sverdrup, H.U., 1947, "Wind-driven currents in a baroclinic ocean; with application to the equatorial currents of the eastern Pacific", Proc. Nat. Acad. Sci. USA, vol. 33, no. 11, pp. 318-326.

12. Balmaseda, M.A., Vidard, A. \& Anderson, D.L.T., 2008, "The ECMWF Ocean Analysis System: ORA-S3”, Mon. Wea. Rev., vol.136, no. 8, pp. 3018-3034, doi: 10.1175/2008MWR2433.1.

13. Uppala, S.M., Kallberg, P.W. \& Simmons, A.J. [et al.], 2005, “The ERA-40 reanalysis”, Quart. J. Roy. Meteor. Soc., vol. 131B, no. 612, pp. 2961 - 3012, doi: 10.1256/qj.04.176.

14. Polonskii, A.B., Shokurova, I.G. \& Sukhonos, P.A., 2013, "Izmenchivost' zavikhrennosti napryazheniya treniya vetra nad Severnoy Atlantikoy [Variability of the wind stress curl over the North Atlantic]", Ekologicheskaya bezopasnost' pribrezhnoy $i$ shel'fovoy zon $i$ kompleksnoe ispol'zovanie resursov shel'fa, vol. 27, pp. 200-205 (in Russian).

15. Artamonov, Yu.V., Bulgakov, N.P. \& Polonskii, A.B., 1993, "Krupnomasshtabnaya struktura i izmenchivost' okeanograficheskikh poley severnoy chasti Tropicheskoy Atlantiki [Largescale structure and variability of oceanographic fields in the north part of the Tropical Atlantic]", Gidrofizika Tropicheskoy Atlantiki, edited by V.N. Eremeev, Kiev, Naukova Dumka, pp. 7-34 (in Russian).

16. Garzoli, S.L., Katz, E.J., 1983, "The forced annual reversal of the Atlantic North Equatorial Countercurrent”, J. Phys. Oceanogr., vol. 13, no. 11, pp. 2082-2090. 
17. Stramma, L., Isemer, H.J., 1988, "Seasonal variability of meridional temperature fluxes in the eastern North Atlantic Ocean”, J. Mar. Res., vol. 46, no. 2, pp. 281-299.

18. Richardson, P.L., McKee, T.K., 1984, "Average seasonal variation of the Atlantic equatorial currents from historical ship drifts”, J. Phys. Oceanogr., vol. 14, no. 7, pp. 1226-1238.

19. Sarkisyan, A.S., 2006, “Sorok let otkrytiyu roli sovmestnogo effekta baroklinnosti i rel'efa dna $v$ modelirovanii klimaticheskikh kharakteristik okeana [40 years of discovery of the joint effect of baroclinity and bottom relief in simulation of the ocean climatic characteristics]", Izv. RAN. Fizika atmosfery i okeana, vol. 42, no. 5, pp. 582-603 (in Russian).

20. Stramma, L., Siedler, G., 1988, "Seasonal changes in the North Atlantic subtropical gyre”, $J$. Geophys. Res., vol. 93, no. C7, pp. 8111-8118.

21. Iselin, C., 1940, "Preliminary report on long-period variations in the transport of the Gulf Stream System”, Pap. Phys. Oceanogr. Meteorol., vol. 8, no. 1, 40 p.

22. Jia, Y., 2000, "Formation of an Azores Current due to the Mediterranean overflow in a modeling study of the North Atlantic”, J. Phys. Oceanogr., vol. 30, no. 9, pp. 2342-2358.

23. Ozgokmen, T.M., Chassignet, E.P. \& Rooth, C.G.H., 2001, "On the connection between the Mediterranean outflow and the Azores Current”, J. Phys. Oceanogr., vol. 31, no. 2, pp. 461480.

24. Spall, M.A., 2000, "Buoyancy-forced circulations around islands and ridges", J. Mar. Res., vol. 58, no. 6, pp. 957-982.

25. Klein, B., Siedler, G., 1989, “On the origin of the Azores Current”, J. Geophys. Res.: Oceans (1978-2012), vol. 94, no. C5, pp. 6159-6168.

26. Niiler, P.P., Maximenko, N.A. \& McWilliams, J.C., 2003, "Dynamically balanced absolute sea level of the global ocean derived from near-surface velocity observations”, Geophys. Res. Lett., vol. 30, no. 22, doi: 10.1029/2003GL018628.

27. Wang, C., 2007, "Variability of the Caribbean low-level jet and its relations to climate", Clim. Dyn., vol. 29, no. 4, pp. 411-422.

28. Fuglister, F.C., 1951, “Annual variations in current speeds in the Gulf Stream system”, $J$. Mar. Res., vol. 10, no. 1, pp. 119-127.

29. Suchovei, V. Ph., 1977, "Izmenchivost' gidrologicheskikh usloviy Atlanticheskogo okeana [Variability of the Atlantic Ocean hydrological conditions]”, Kiev, Naukova Dumka, 1977, 215 p. (in Russian).

30. Lee, T.N., Johns, W.E. \& Zantopp, R.J. [et al.], 1996, "Moored observations of western boundary current variability and thermohaline circulation at 26.5 in the subtropical North Atlantic”, J. Phys. Oceanogr., vol. 26, no. 6, pp. 962-983. 